\title{
Monitoring the quality of water from isolated marshes resulting from opencast and underground mining of the Sieniawa lignite deposit
}

\author{
Grzegorz Galiniak ${ }^{1, *}$, Kazimierz Różkowski ${ }^{1}$ \\ ${ }^{1}$ AGH University of Science and Technology, Al. Mickiewicza 30; 30-059 Krakow, Poland
}

\begin{abstract}
The „Sieniawa” lignite mine is one of the oldest Polish mines extracting lignite by means of both underground and opencast mining. The latter process is carried out until the present day. The transformation of the landscape is the most visible evidence of carrying out mining activities and therefore systematic approach to the reclamation of brownfield sites is a very important element of the mine's environmental policy. The authors present previous experiences and the course of reclamation of post-mining terrains created during the operation of the "Sieniawa" lignite mine. The greatest emphasis is placed on numerous small anthropogenic reservoirs formed as a result of spontaneous flooding due to underground exploitation (surface subsidence) and filling of open pits with water.
\end{abstract}

\section{Introduction}

Mining is one of those branches of industrial activities that bring significant economic benefits, but, on the other hand, inevitably lead to a conflict with the environment. The influence on the natural environment is manifested by a reduction in the amount of natural resources, degradation (sometimes devastation) of mining areas, hydrogeological disturbances, and emissions to the atmosphere. The current Polish law imposes an obligation to conduct reclamation in order to restore the utility values of the affected areas. It should be noted that the modern reclamation has more important goals than just bringing the utility value. Its purpose is to create complex and complete ecosystems in the postmining areas. In this case, the open-pit mining (and lignite mining in particular) and modern reclamation may create new possibilities for the development of water, forest and agricultural ecosystems.

An example of proper approach to the issue of reclamation of post-mining areas and the so-called sustainable management of natural resources can be found in one of the longest operating mines in Poland, namely the "Sieniawa" lignite mine, which can be praised because of the effective and properly conducted reclamation works [1-3].

* Corresponding author: galiniak@agh.edu.pl 


\section{The characteristic of the mine and the deposit}

The "Sieniawa" lignite mine, as the last and at the same time one of the few mines carrying out both the common open-pit and underground mining (Fig. 1.), conducted underground exploitation until 1997. It is estimated that during the fifty years between 1950 and 2001 that preceded the liquidation of the mine and its acquisition by another entity, 6.1 million tonnes of lignite were extracted, from which around 5 million tonnes using underground method. Due to the complicated geological structure, a result of glaciotectonic deformation of young Tertiary sediments, the documented deposits are characterized by relatively small dimensions, strong folding, and significant geometric inconsistency of the folding structures - from symmetrical through overturned, recumbent to returned and scale folds $[4,5]$. Specific geological and mining conditions were associated with the necessity to conduct exploitation within small, separated exploitation fields, containing individual fold structures. The average area of a mining excavation reached up to $5 \mathrm{ha}$, with depth of up to $40 \mathrm{~m}$ above the main water-bearing sublignite level [1, 2, 6, 7]. Usually, after few years of mining activity and depleting the resources, the exploited field was being abandoned and mining activities were being transferred to another field, usually located in close proximity. The abandoned open pits were subjected to reclamation activities characterized by varying degrees of involvement, generally increasing with experience and the growing ecological awareness. In the case of underground mining with roof caving, the empty spaces of the excavations were spontaneously tightened as a result of surface (hanging rocks) subsidence. The deformations propagating towards the surface (in the case of relatively shallow mining excavations) have resulted in the formation of surface troughs and sink-holes directly above the caving area.

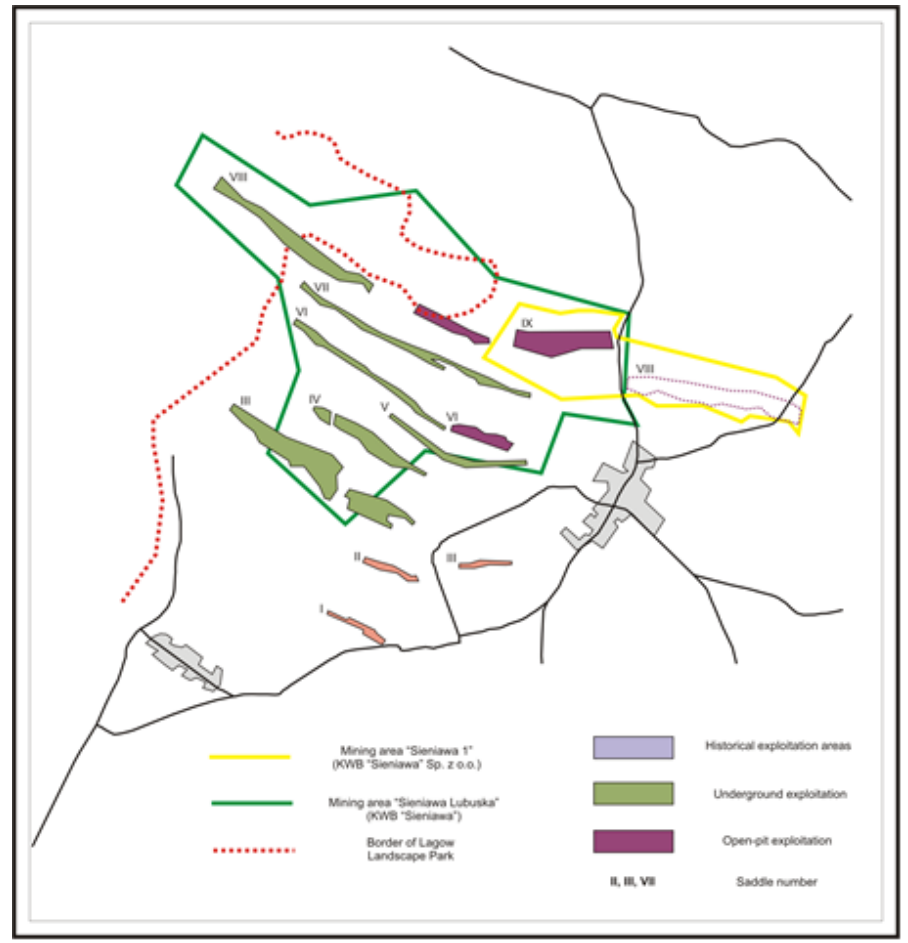

Fig. 1. Historical and present location of exploitation areas. 


\section{Mining and the transformation of the natural environment}

The terrains acquired for both underground and open-pit exploitation were typical end moraine areas, characterized by a high variety of landscape forms. The majority of the area is covered by beech and mixed (beech-pine-birch) forests on brown and rusty soils. The remaining terrains were used as agriculture fields. Additionally, the area was characterized by a lack of developed hydrographic networks with the only exception of temporary (formed during heavy rainfall events) sink-holes filled with water occurring in the area of the No. III and VI saddles [1, 2, 6, 8]

The underground mining activity in the "Sieniawa" lignite mine was carried out in various periods of time in five saddles (No, III, IV, VI, VII, and VIII) while the open-pit method was used to produce lignite in the eastern part of the No. VI saddle and western part of the eastern wing of the No. VII and IX saddles. At present the exploitation is continued in the eastern part of the No. VIII saddle.

The areas of underground mining activities were previously deforested and excluded from forestry activity for around 15 to 20 years, depending on the time of mining works, resources available in the deposit, and character of the rock layers surrounding the seam. Taking into account the seam thickness, mining method (caving without backfilling) and the depth of the exploitation, the negative impact on the environment was manifested with numerous craters with diameter of up to several meters, ditches, and steps of up to a few meters deep and several meters long. As the result of deformations, the soil structure was damaged, especially in the areas of landslides, slopes, and steps. The fertile top layer of soil was scraped and the lower layers of sand and sandy clays were exposed. The silt and clay isolating layers above and below the lignite seam were the reason why the exploitation has not influenced the complex water conditions. In some of the sink-holes located over the silt basis, small water ponds (fitting very well into the existing landscape character) were formed.

Underground mining activities have resulted in anthropogenic transformation of an area reaching some 101.71 ha with almost 3245 meters of forest roads destroyed or damaged. This caused indirect but significant problems in transport in the area of ca. 500 ha located between the saddles and in the forest areas surrounding the mine.

The environmental impact of the open-pit mining activity has resulted in the occurrence of significant transformations of post-mining elements, namely pits and dumps. These mining objects are characterized are reaching up to a few hectares, while their depth (height) is up to several meters $[6,9,10]$.

\section{Description and assessment of the reclamation works}

Taking into account that the majority of post-mining grounds were classified as class $\mathrm{C}$ and the fact that the areas acquired for mining activity were previously deforested it was decided that forest reclamation will be the main method of reclamation. Additionally, this decision was supported by the fact that in the 70s of 20th century the "Sieniawa" lignite mine passed over 20 ha of reclaimed lands (the No. III saddle) to State Forests National Forest Holding. During this time, the so-called artificial reforestation was carried out. The main activities included removing trees older than 35 years from the mining area and replacing them with young plants. The new forest more easily adapted itself to the surface deformations and new environmental conditions. Taking into account that some of the saddles were reclamated already during the mining process, it seemed reasonable to divide the reclamation process into two parts. The first one comprised of preparing the reclaimed areas for planting and the other included works and activities related to planting and nurturing the young trees. 
The decision to choose forest reclamation as the leading method in the post-mining areas of the "Sieniawa" lignite mine was preceded by numerous consultations with the representatives of local authorities, State Forests National Forest Holding, and the managers of the mine. The local authorities demanded the reclamation of both the lands acquired for mining activity and those neighboring the mining area. However, no specified demands were given concerning the method of reforestation. Such requirements were, however, given by the representatives of State Forests; a special attention was paid to the fertile layer of soil and the introduction of productive species. The presented attitude is typical for State Forests National Forest Holding which in most cases is administering the reclaimed post-mining terrains.

In general, between 1957 and 1998, Świebodzin, Sieniawa and Łagów Forest Inspectorates passed over 136 ha of forest to the "Sieniawa" lignite mine, while between 1992 and 2002 the mine passed almost 127 ha of reclaimed grounds to the Świebodzin Forest Inspectorate, including 120 ha of areas ready for planting. The remaining part consisted of roads, ponds, and forest dividing-lines [1,2]

In the more long-term perspective of 9 to 19 years after the reclamation works in particular saddles, it can be stated that the forest reclamation was carried out without significant complications and the results are satisfying. The mix of tree species was properly chosen. The reclaimed lands are not different than the surrounding areas. Simultaneously, they provide a habitat for animals, contributing to the increase in their population.

Additionally, small water reservoirs with defined morphology were created in the final lignite pits and in the specially formed troughs without run-off located in the reclaimed areas thanks to the inflow of groundwater and precipitation of water, leading to an increase in the habitat's attractiveness (Fig. 2). Simultaneously, in the areas of troughs above the underground cavings, isolated marshes reaching area of 0.78 ha (Jezioro Ciche) were formed (Fig. 3) as a result of ground subsidence below the shallow groundwater level.

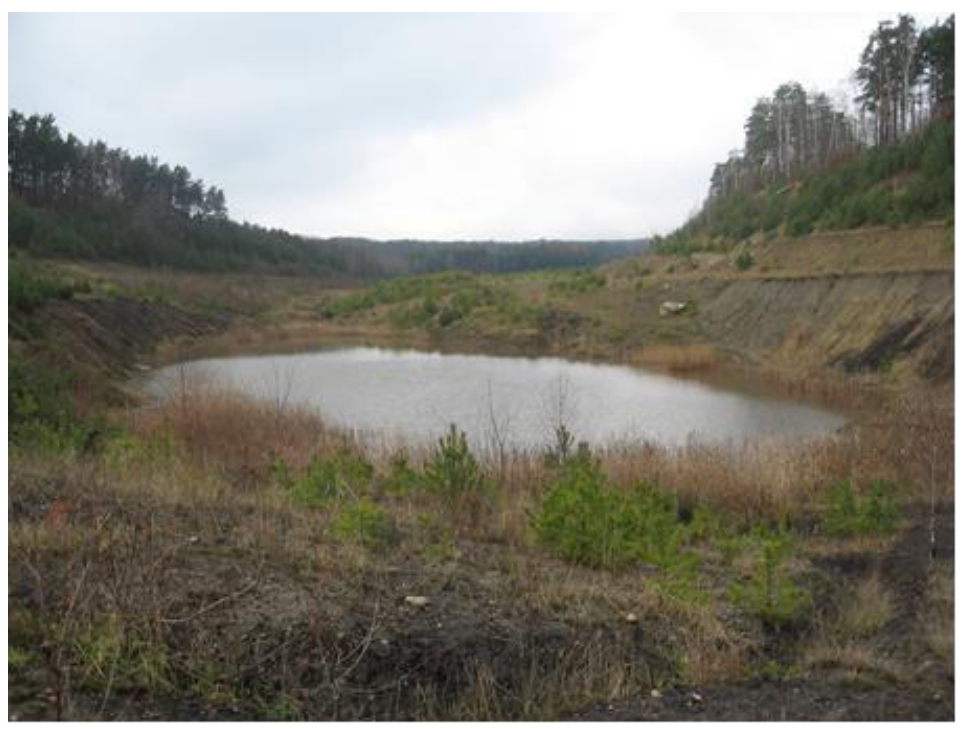

Fig. 2. The anthropogenic reservoir created in a pit of a former open cast mine - saddle No. VI; photo by G. Galiniak. 


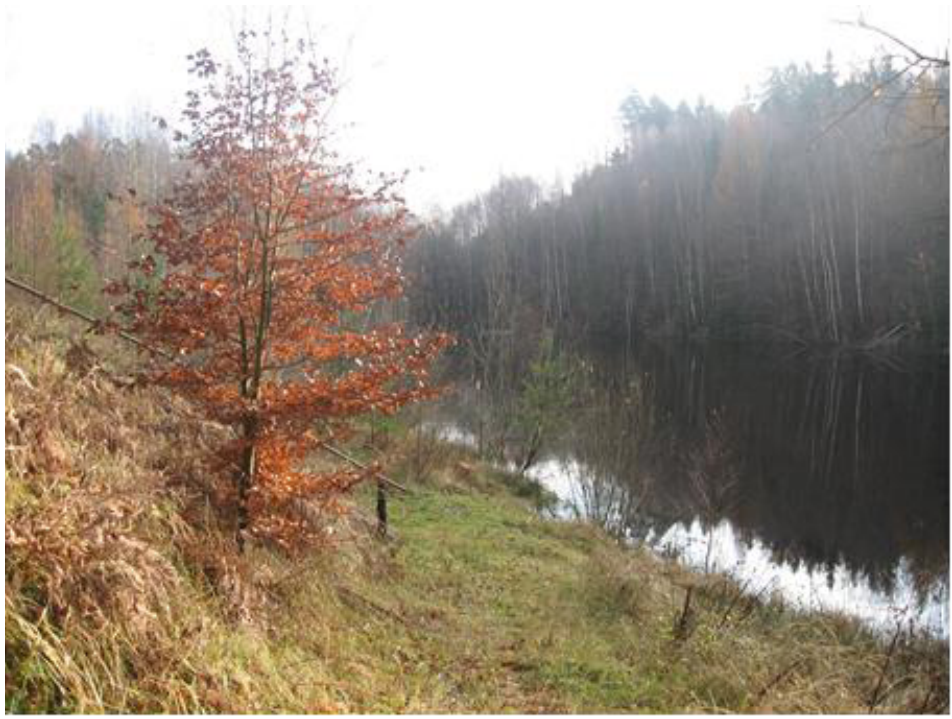

Fig. 3. The anthropogenic reservoir ("The Silent Lake") in a sink-hole created as a result of underground exploitation - saddle No. VII; photo by G. Galiniak.

When analyzing the effects of previously conducted reclamation works, a preliminary analysis, based on a limited range of physical and chemical parameters, of the chemical composition of water from the reservoirs created in the post-mining terrains, was performed. In total, water from eight different reservoirs, representing the previouslymentioned types, was analyzed (Fig. 4). The samples were equally split between the classes. In the case of two biggest ones, with depths, determined by probing, exceeding 5.0 and 7.5 meters, multiple sampling was used as three samples were collected: from the bottom, middle, and near-surface zones. For the sake of comparison, an additional sample was collected from a well drilled for mine supply, filtered within the Quaternary aquifer (Fig. 4).

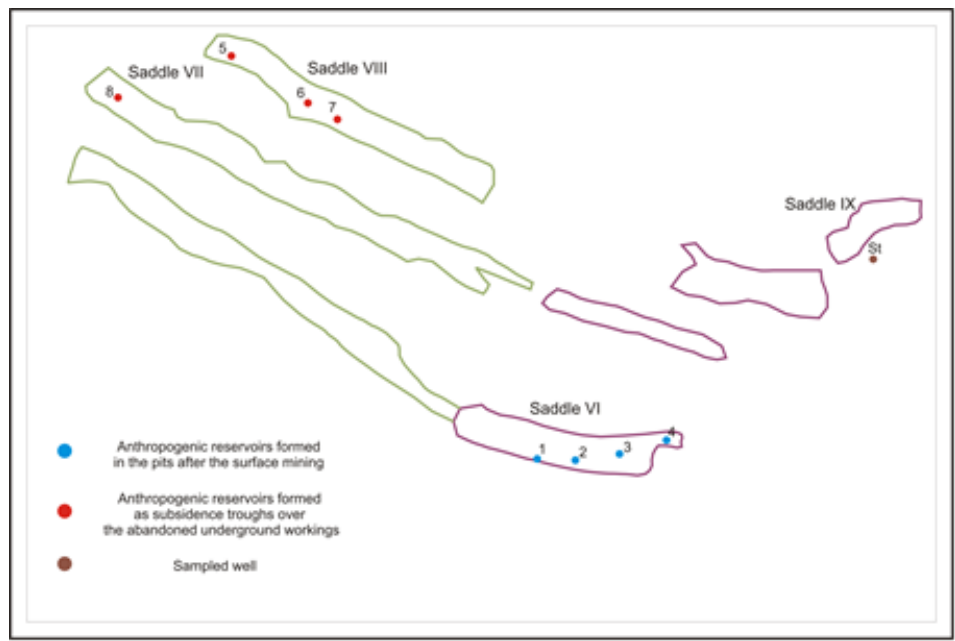

Fig. 4. The location of water samples collection.

Genetic dissimilarity between the individual types of the formed water reservoirs has found its reflection in the chemical variability of water filling particular troughs $[11,12]$. The initial point was the different mineralization, although only fresh water was present 
within the area studied. Higher values in the range $161-431 \mathrm{mg} / \mathrm{dm}^{3}$ were associated with the artificially formed reservoirs in the former open pits. Selective dumping of overburden material, which was used to form the reservoir structure, allowed avoiding a long-term contact between water and lignite residues. An analysis of ion composition of water indicated relatively low concentration of sulphate ions in comparison to the reservoirs filling the lignite pits known from the literature, marked within the range of $49.8-112.6 \mathrm{mg} / \mathrm{dm}^{3}$. They constitute from 31.4 to $47.1 \%$ mval of anions, remaining in minority in comparison to bicarbonate ions commonly existing in surface and shallow groundwater. With water reaction oscillating around neutral, from weakly acid to weakly alkaline, the total iron concentration did not exceed $0.71 \mathrm{mg} / \mathrm{dm}^{3}$. With the exception of iron and manganese, which concentrations an order of magnitude higher, and slightly elevated concentration of chlorides, the analyzed water samples were similar to those collected from the Quaternary well with a mineralization of $247.8 \mathrm{mg} / \mathrm{dm}^{3}$. Similar characteristic was presented by A. Mizera who described the Quaternary water level in "The documentation of reclamation of post-mining areas in the No.VI and VIII saddle of the "Sieniawa" lignite mine (in liquidation) located in Sieniawa Lubuska".

The troughs formed as a result of subsidence of ground above tightened spaces created lowerings without run-off which, after some time, were filled with water. Because of a compact and loose character of the roof layers, partially with isolating character, accompanied with the lack of overburden layers of the disturbed structure and increased specific area, the filling waters are characterized with even lower mineralization than the samples collected from the terrains affected by the open-pit mining. Within the collected samples the total dissolved substance did not exceed $182 \mathrm{mg} / \mathrm{dm}^{3}$, with $\mathrm{pH}$ value ranging from weakly acidic to weakly alkaline. The lowering of terrain, often significantly below the surrounding area, and deforestation of the border area, resulted in limiting the wind operation and decreased the water-mixing capability. With the limited mixing capability, the oxygen concentration in the water decreases quickly, leading to the formation of reducing environment. In the deepest reservoir, The Silent Lake, with bottom located significantly lower than the surrounding terrain, a typical stratification was created, which was emphasized by the drop of temperature from $18.9^{\circ} \mathrm{C}$ in the near-surface zone (epilimnion) to $8.3^{\circ} \mathrm{C}$ in the bottom zone (hypolimnion). The drop in total mineralization of the water is most likely related to the ongoing process of water demineralization, observed and described by A. Jędrczak and A. Gontaszewska in the area of Muskau Bend [9, 12, 13, $14,15]$. The progressive oxidation of sulphates has led to a drop in their concentration, well below the detection limit of the measuring equipment, with maximal detected concentration in the shallow waters reaching $1.29 \mathrm{mg} / \mathrm{dm}^{3}$. The waters filling the subsidence troughs were characterized with simultaneous high concentrations of total iron, up to $2.85 \mathrm{mg} / \mathrm{dm}^{3}$, in near-surface waters, and at the depth of over seven meters in the monimolimnion layer up to $15.55 \mathrm{mg} / \mathrm{dm}^{3}$ ).

\section{Summary}

The „Sieniawa” lignite mine is a perfect example of harmonious cooperation with the surrounding environment over a 60 -year period of the deposit exploitation. The reclamation carried out in the post-mining areas and the care for the natural environment, both in the neighboring terrains and in the mining area, have contributed to the establishment of the Łagów Landscape Park in 1985. At the moment, the mining is conducted on relatively low scale, without damage to the natural environment. The currently conducted reclamation considerable reduces the negative impact of mining. When compared to other Polish lignite mines, the production in Sieniawa is significantly lower, but the reclamation activities are as relevant as in the larger mines. Reclamation is conducted professionally and in line with 
the guidelines, which was confirmed by the National Fund for Environmental Protection and Water Management and the Ministries of Economy, State Treasury, and Environment. The aforementioned opinions are shared by foresters from all over the country visiting the mine and surrounding areas.

The work has been conducted on the AGH's Faculty of Mining and Geoengineering within the frame of Research Project No. 11.11.100.597.

\section{References}

1. G. Galiniak, J. Jarosz, R. Tomaszewski, Górnictwo i Geoinżynieria, 34 (4) 167-178 (2010)

2. G. Galiniak, J. Jarosz, Zeszyty Naukowe Uniwersytetu Zielonogórskiego - Inżynieria Środowiska, 17 (137) 180-188 (2010)

3. K. Różkowski, K. Polak, M. Cała, Górnictwo i Geoinżynieria, 34 (4), 517-525 (2010)

4. A. Gontaszewska, Hereditas Minariorum 2, 51-65 (2015)

5. M. Piwocki, Węgiel Brunatny, 2, 11-15 (2003)

6. L. Kozacki, Seria Geografia 21 (1980).

7. J. Żaba, Geologia, 1 (1977)

8. L. Kozacki, Badania geologiczno-inżynierskie dla potrzeb budownictwa na obszarach zaburzonych glacitektonicznie Ziemi Lubuskiej, (1974)

9. Gontaszewska, A. Kraiński., Prace Naukowe GIG. Górnictwo i Środowisko, 3, 221-234 (2007)

10. A. Gontaszewska, A. Kraiński, Wybrane problemy badań geologicznych i hydrogeologicznych dla górnictwa i energetyki, 108-119 (2012)

11. D. Bedla, A. Misztal, Annual Set The Environment Protection, 16, 421-439 (2014)

12. E. Jaruchiewicz, Environmental \& Socio-economic Studies, 2 (1), 16-26 (2015)

13. A. Jędrczak, Wydawnictwo Wyższej Szkoły Inżynierskiej w Zielonej Górze (1992)

14. K. Labus, S. Skoczyńska, Geol Q, 57 (3), 561-566 (2013)

15. S. Lutyńska, K. Labus, Arch Environ Prot, 41 (3), 60-69 (2015) 